Akreditasi KEMENRISTEKDIKTI, Nomor: 148/M/KPT/2020
http://jurnal.stkippersada.ac.id/jurnal/index.php/VoX

\title{
ANALISIS KESALAHAN PENGGUNAAN KATA BILANGAN UNIVERSAL "SEMUA, SEGALA, SELURUH DAN SEGENAP" PADA PEMULA PELAJAR MANDARIN INDONESIA
}

\author{
Susanto \\ Progam Studi Bahasa Mandarin, Sekolah Tinggi Bahasa Harapan Bersama \\ Email:susanto.zhou92@gmail.com
}

INFO ARTIKEL
Riwayat Artikel:
Menerima $: 28$ Mei 2021
Revisi $\quad: 12$ Agustus 2021
Diterima $: 12$ Oktober 2021

Kata Kunci:

kesalahan penggunaan, kata bilangan se-, pelajar indonesia

\author{
Keywords: \\ Usage errors, number words, \\ Indonesian students
}

\section{Korespondensi:}

\section{Susanto}

Progam Studi Bahasa Mandarin, Sekolah Tinggi Bahasa Mandarin Bersama

Email:

susanto.zhou92@gmail.com

\begin{abstract}
ABSTRAK
Penelitian ini terutama ditujukan untuk analisis penguasaan dan kesalahan kata bilangan universal "semua", "segala" , "seluruh" dan "segenap" mahasiswa Indonesia dalam belajar bahasa Mandarin. Didalam Bahasa Indonesia juga memiliki kata bilangan yang serupa ini, tetapi kata bilangan tersebut masih berbeda dengan bilangan universal dalam bahasa mandarin. Oleh karena itu, mahasiswa Indonesia lebih cenderung membuat kesalahan saat mempelajari kata bilangan ini. Secara umum, tingkat terjadinya kesalahan lebih condong ke pembelajar pemula, penyebabnya yaitu pengaruh negatif dari bahasa ibu dan pemahaman bahasa mandarin yang tidak cukup dalam. Penulis menggunakan metode kualitatif dalam penelitian ini, dan didapatkan kesimpulan bahwa pelajar Indonesia mengalami kesulitan dalam menggunakan kata bantu bilangan universal bahasa Mandarin"semua", "segala" , "seluruh" dan "segenap" yaitu mereka tidak bisa membedakan pemakaian keempat kata bilangan tersebut.
\end{abstract}

\section{ABSTRACT}

This article is mainly aimed at analyzing the mastery and errors of universal number words "所有, 一切, 全部” Indonesian students in learning Chinese. In Indonesian it also has a similar number word, but the number word is still different from the universal number in Chinese language. Therefore, Indonesian students are more likely to make mistakes when learning these number words. In general, the error rate is more likely for the beginner Chinese learners, the negative influence of the mother language and the insufficient understanding of the Chinese language. This analysis is based on the situation of beginner level students learning Chinese in Indonesia.

\section{PENDAHULUAN}

Dengan perkembangannya ekonomi negara tiongkok, Bahasa mandarin berkembang dengan sangat pesat di berbagai negara termasuk juga negara indonesia. Untuk saat ini, orang-orang yang belajar Bahasa mandarin semakin meningkat, tidak lagi hanya etnis tionghua yang belajar Bahasa mandarin, dengan pengaruhnya etnis tionghua, etnis lainya yang belajar mandarin juga semakin meningkat. Indonesia adalah negara yang terdiri dari berbagai macam suku, oleh sebab itu Bahasa mandarin adalah Bahasa asing pilihan kedua, ketiga, bahkan pilihan ke empatnya, dibawah latar belakang berbagai Bahasa ini, membawakan pengaruh yang sangat besar untuk pemula Bahasa mandarin. Perbedaan fonetik, kosakata, ungkapan dan 
grammar Bahasa mandarin sangat jelas dibandingkan dengan Bahasa lainnya, dan tentu saja peraturan bahasanya masi serupa. Adanya semantik, konteks, dan lainnya dalam tata Bahasa mandarin, sehingga menyulitkan orang yang belajar bahasa Mandarin untuk memahaminya. Selain itu, banyak sinonim yang membuat pemula mudah bingung, oleh karena itu "sinonim" dalam pengajaran tetaplah layak dipelajari dan diteliti.

Pada saat proses mengajar, sering kali menemukan disaat mahasiswa belajar kata bilangan "semua, seluruh, segala dan segenap, sering melalukan kesalahan dalam pemakaian kata bilangan tersebut. Oleh karena itu, artikel ini menganalisis kata bilang "semua, seluruh, segala dan segenap", dalam pembelajarannya apakah adanya pengaruh dari lingkungan belajar dan tingkatan ilmu bahasa mandarin mahasiswa. Melalui analisis dan penelitian ini, memperoleh cara yang lebih baik untuk memperbaiki penyalahgunaan kata bilangan "semua, seluruh, segala dan segenap" dalam pengajaran.

Tujuan dari penelitian ini adalah untuk lebih memahami situasi siswa Indonesia dalam belajar atau menggunakan kata bilangan universal, untuk memecahkan kesulitan yang dihadapi siswa dalam mempelajari kata bilangan universal, dan mengusulkan solusi dan saran untuk memecahkan masalah. ' mengajar dan belajar siswa.

Arti penting dari penelitian ini adalah untuk membantu siswa memecahkan masalah yang sering muncul dalam perolehan kata bilangan universal dalam Bahasa Mandarin , dan sekaligus mengajukan beberapa saran pengajaran untuk guru, yang dapat memberikan referensi untuk pengajaran bahasa Mandarin.

\section{METODE PENELITIAN}

Ditinjau dari rumusan masalah yang diteliti, maka bentuk penelitian ini dapat digolongkan dalam penelitian kualitatif. Moleong (2011.4) menyatakan penelitian kuanlitatif adalah penelitian yang menghasilkan data deskriptif berupa kata-kata tertulis atau lisan dari orangorang dan perilaku yang dapat diamati. Menurut Sugiyono (Sugiyono, 2012) analisi data adalah kegiatan pencarian dan penyusunan data dari proses wawancara secara teratur, sehingga lebih mudah dimengerti dan hasil analisi data dapat lebih mudah diinformasikan kepada orang lain. Penulis mengumpulkan data dengan memberikan contoh kalimat tentang kata bilangan universal buat mahasiswa. Dengan melalui pembagian kuesioner dan wawancara terhadap mahasiswa sekolah tinggi Bahasa harapan Bersama, agar dapat lebih memahami kemampuan pengertian mahasiswa tentang kata bilangan universal.

Sumber data dalam penelitian ini adalah mahasiswa STBHB yang pemula belajar Bahasa mandarin. terhadap penelitian sebanyak 3 kelas (100 mahasiswa), selama proses pembelajaran akan dilaksanakan test pada setiap kata bilangan yang baru yang bertujuan untuk mengetahui kemampuan pemahaman mahasiswa dalam kata bilangan universal Bahasa mandarin. 
HASIL DAN PEMBAHASAN

kata bilangan universal "semua", "seluruh" dan "segala" dalam Bahasa mandarin

“所有”、“全部”与 “一切” dalam istilah umum bisa diartikan menyimpulkan, kata bilangan tersebut adalah kata-kata yang umum digunakan dalam bahasa mandarin modern. Ketiga kata bilangan ini memiliki kebersamaan dan individualitas dalam penggunaannya. Terkadang ketiganya dapat dipertukarkan, terkadang tidak bisa.

1.1 makna dari ketiga kata bilangan

1.1.1 Makna dari“全部”

“全 部” menekankan keutuhan dari benda itu sendiri, yaitu memperlakukan objek secara keseluruhan. Keseluruhan ini mencakup dua kondisi, (1) Hal-hal itu sendiri tidak dapat dibagi atau diukur, (2) Meskipun benda-benda terdiri dari beberapa bagian, tetapi hubungan antara bagianbagian itu sangat erat.

1.1.2 Makna dari “所有”

" 所有 " mengutamakan menekankan penjumlahan benda, dan lebih berfokus pada peringkasan individu yang relatif independen, dan tidak ada persyaratan untuk korelasi yang erat antara individu.

\subsubsection{Makna dari “一切”}

" 一 切 " berfokus pada generalisasi jenis-jenis benda. Dibandingkan dengan kata bilangan “全部”dan “所 有”, cakupan kata benda yang dimodifikasi oleh "一切 " akan lebih kecil, karena hanya dapat memodifikasi hal-hal yang dapat dikategorikan, bukan hal-hal yang tidak dapat diklasifikasikan. kata bilangan “全部”dan “所有” tidak memiliki batasan ini.

1.2 Perbedaan dari ketiga kata bilangan

Arti umum dari ketiganya kata bilangan ini menunjukkan keseluruhan, kesimpulan. Namun nyatanya, masih terdapat beberapa perbedaan yang halus, dan cara untuk mencapai generalisasinya pun berbeda. Dalam kondisi tertentu, ketiga kata bilangan ini dapat saling menukar posisi pada saat penggunaannya.

1.2.1 Syarat pertukaran ketiga kata bilangan dalam posisi atributif

$\begin{array}{lr}\text { Untuk } & \text { saling } \\ \text { menggantikan, yang } & \text { harus } \\ \text { dimiliki adalah kata yang } & \text { harus } \\ \text { dimodifikasi } & \\ \text { merupakan keseluruhan yang } \\ \text { dapat dikategorikan, dapat } \\ \text { dibagi, atau dapat diukur. } \\ \text { Kedua, objek harus }\end{array}$


memiliki batas lingkup yang jelas, yang cukup untuk menggantikan ketiganya.

Contoh:

(1) 我把自己的所有希望 都寄托于他。 我把自己的全部希望 都寄托于他。 我把自己的一切希望 都寄托于他。

（2）小明的所有想法被全 班采用。

小明的全部想法被全 班采用。

小明的一切想法被全 班采用。

(1) kosakata“希望”bisa berlipat ganda penggunaannya, sedangkan “自己的 "membatasi cakupannya.

Demikian pula (2) “想法”juga multipel dan dapat diklasifikasikan, sementara “ 小明的” menunjukkan pikiran Xiao Ming dan bukan objek orang lain. Oleh karena itu, kedua contoh ini diperbolehkan untuk dipertukarkan jika memenuhi syarat pertukaran.

1.3 Perbedaan dari ketiga kata bilangan

Seperti yang telah disebutkan di atas, ketiganya secara umum dianggap sebagai kesimpulan, namun dari segi semantik tertentu tetap memiliki ciri dan kepribadian masingmasing.

1.3.1 Fokus semantik berbeda

Perbedaan dalam semantik menentukan individualitas dari penggunaan ketiga kata bilangan tersebut. Yang kita ketahui, “全部” terutama menekankan pada integritas benda, dan benda tersebut tidak dapat dibagi atau dikuantifikasi, meskipun benda terdiri dari beberapa bagian, tetapi semua bagian benda dituntut untuk berhubungan erat.

（1） 他并不真正了解 事情发生的全部 过程。

*他并不真正了解事

情发生的所有过程。

*他并不真正了 解事情发生的二 切过程。

（2）这是初级班的全 部学生名单。

*这是初级班的 所有学生名单。

*这是初级班的

一切学生名单。

Contoh （1）“事情 发生过程” disusun dengan beberapa tautan, tetapi setiap tautan terkait erat, jika kurang satu bagian dari itu, maka tidak dapat membentuk proses yang 
lengkap. Di sini, “所有”, “

一 切 " tidak dapat menggantikan penggunaan “ 全部”, karena “所有”tidak mengharuskan masalah atau benda untuk berhubungan erat, dan “- - 切” juga memerlukan hal-hal yang dapat diklasifikasikan.

Contoh (2) Meskipun “学生”adalah individu yang relatif mandiri, tetapi mereka juga bagian dari kelas dasar, secara keseluruhan, mereka dibedakan dari teman sekelas yang lain, jadi paling tepat menggunakan “全部” untuk memodifikasi, sama seperti dua kata bilangan lainnya yang tidak memenuhi syarat kalimat. Meskipun “所有” terutama menekankan jumlah kuantitas, tetapi lebih berfokus pada individu yang relatif independen, dan tidak memerlukan koneksi yang dekat.

（3）这就是宇宙所有生命的 集中地。

*这就是宇宙全部生命 的集中地。

*这就是宇宙一切生命 的集中地。
（4）在快速航行的飞船里 所有过程, 都比地面上相同的 过程慢些。

（5） *在快速航行的飞船 里全部过程, 都比地面上相同 的过程慢些。

*在快速航行的飞船里 一切过程, 都比地面上 相同的过程慢些。

Contoh (3) kehidupan tanpa batas di alam semesta, dan semuanya relatif independen, jadi “ 所有 "digunakan untuk memodifikasi. Bandingkan contoh(1) dengan (4), (1) “事情发 生的过程 "mengacu pada keseluruhan proses, sedangkan (4) dalam “所有过程 ”mencakup banyak peristiwa, seperti "getaran atom", "gerakan jarum jam" dan sebagainya yang masing-masing merupakan ringkasan dari “过程” yang relatif independen dan tidak terkait satu sama lain sebelumnya. Setelah itu adalah“一切”, yang berfokus pada generalisasi jenisjenis hal, dibandingkan dengan dua yang pertama, cakupan “一 一切 "seringkali lebih kecil, yang memodifikasi hal-hal yang dapat dikategorikan.

1.3.2 Perbedaan akurasi dari ketiga kata bilangan

Akurasi mengacu pada sejauh mana objek yang 
dirujuk oleh komponen kata benda dapat ditentukan oleh orang. Di antara ketiganya,“ 全部”adalah akurasi derajat tertinggi, sebaliknya“ 一 切 "adalah yang terkecil, dan “ 所有” ada di antara mereka.

Contoh:

(1) 全部报告都已经检查过了。

*一切报告都已经检查过了。

(2) 二切车辆不得入内。

*全部车辆不得入内。

Contoh pertama (1) menggambarkan sesuatu yang telah terjadi, dan pada saat yang sama telah menentukan apa yang telah laporan. Sebaliknya, rentang objek dari“一切” tak tentu, jadi “全部”lebih tepat, terlihat bahwa “所有 "juga bisa digunakan untuk memodifikasi kalimat. Contoh kedua (2) Jelaskan bahwa apa pun jenis kendaraan yang dilarang masuk, apakah itu kendaraan yang dikenal atau tidak, dari sudut pandang subjek, terapkan "segala sesuatu" untuk dimodifikasi. Jika itu "semua", tidak langsung menunjukkan bahwa peringatan dikeluarkan untuk kendaraan di depan Anda, dan efeknya tidak terlalu baik. Dapat dilihat bahwa mengubah ke "semua" juga akan berdampak buruk pada "semua". Di sini dapat dikatakan bahwa "semua" umumnya digunakan dalam kalimat bentuk lampau, sedangkan "semua" digunakan dalam kalimat sekarang atau yang akan datang. "Semua" dapat digunakan di masa lalu, sekarang, dan masa depan, selama tidak mengubah arti yang ingin
Anda ungkapkan, Anda dapat menggunakan "semua" untuk memodifikasi.

\section{Kata Bilangan Universal dalam Bahasa}

Indonesia "Semua", "Seluruh", "Segala" dan "Segenap"

Terdapat kata bantu bilangan universal yang khusus dalam bahasa Mandarin, tetapi dalam bahasa Inggris, hanya terdapat "All" yang berarti keseluruhan, terlihat bahwa dalam Bahasa Indonesia juga terdapat kata bantu bilangan universal yang mirip dengan bahasa Mandarin. Misalnya "semua", "segala", "seluruh" dan "segenap", ketentuan yang terdapat dalam setiap kata-kata ini menunjukkan ciri khasnya masing-masing, kata-kata ini memiliki makna yang sama yaitu keseluruhan, tetapi tetap terdapat sedikit perbedaan.

\subsection{Makna "Semua"}

"Semua" berarti penggabungan dari banyaknya suatu benda atau hal, yaitu benda yang dapat dikategorikan, atau benda yang banyak jenisnya. "Semua" adalah kata yang independen, yang bisa diletakkan pada sebelum atau sesudah kata benda atau hal yang mengikutinya. Terlihat bahwa, ruang lingkup "Semua" relatif besar. Ketentuan kata "Semua" sama dengan kata "所有" dalam bahasa Mandarin, namun dalam situasi tertentu juga bisa berarti "全部" atau "一切". Misalnya:

\section{(1) Semua murid sudah masuk ke kelas.}

所有的学生都已经进教 室里了。 
(2) Barang yang ada disini semuanya milik dia.

这里的东西全部都是他 的。

Contoh (1) "siswa" berjumlah banyak, sebagai kata yang independen, bisa diterjemahkan dengan "所有". Karena di atas telah disebutkan bahwa kata "Semua" bisa diletakkan sebelum dan sesudah benda yang mengikutinya, jadi apabila kata "Semua" diletakkan di depan benda yang mengikutinya, maka akan diterjemahkan menjadi " 所有 ", sebaliknya, akan diterjemahkan menjadi “全部 ”. Contoh (2) Jika diganti dengan "所有", tidak dapat menunjukkan bahwa ia diletakkan di belakang benda, sehingga penggunaan "全部" lebih tepat. Selain itu, karena ruang lingkup "Semua" lebih luas, maka dapat juga digunakan dalam kalimat kala akan datang.

\subsection{Makna "Seluruh"}

Yang ditekankan dalam kata "Seluruh" adalah kesatuan dari benda atau hal, sehingga tidak dapat digunakan pada benda atau hal-hal yang banyak jenisnya atau yang dapat diklasifikasikan. Posisi "Seluruh" diletakkan di depan benda atau hal yang mengikuti. Sesuai dengan makna di atas, "全部" digunakan untuk menerjemahkan "Seluruh". Misalnya:

\section{(1) Seluruh penonton telah masuk ke dalam bioskop. 全部的观众已经进电影 院了。}

Contoh (1) "观众” atau "penonton" adalah satu kesatuan yang menonton film yang sama, dan kalimat tersebut menyatakan suatu peristiwa yang telah terjadi, sehingga memenuhi syarat penggunaan "全 部 ", membuktikan bahwa "Seluruh" dapat diterjemahkan dengan "全部" .

3.3 Makna "Segala"

"Segala" menekankan pada benda atau hal yang banyak jenisnya, atau benda yang dapat dikategorikan. Misalnya:

(1) Segala permasalahan akan di selesaikan.

\section{所有事情都会解决的。 全部事情都会解决的。 一切事情都会解决的。}

Contoh (1) " 事 情 " atau "Permasalahan" adalah hal yang dapat dikategorikan. Ketentuan penggunaan "Segala" sama persis dengan ketentuan "全部", "所有", dan "一切" sehingga dapat diganti satu sama lain dan bisa diterjemahkan dengan ketiganya. 3.4 Makna "Segenap"

Makna "Segenap" mirip dengan makna "Seluruh", yang menekankan pada keutuhan hal-hal, akan tetapi "segenap" hanya bisa diikuti dengan kata-kata yang berkaitan dengan manusia sehingga lebih terbatas ruang lingkupnya. Misalnya:

(1) Terhadap hal ini segenap rakyat Indonesia turut berduka cita.

对于这件事全部的印尼人 感到非常难过。

对于这件事所有的印尼人 感到非常难过。 
Contoh (1) "印尼人 " atau “Orang Indonesia" adalah satu kelompok yang utuh, yang juga melibatkan "manusia", sehingga selama berkaitan dengan manusia, selalu menggunakan kata "Segenap". Seringkali, "全 部" dan "所有 " dapat digunakan untuk menerjemahkan "Segenap".

\section{Perbandingan kata bantu bilangan dalam}

\section{Bahasa Indonesia - Bahasa Mandarin}

Kata bantu bilangan universal dalam bahasa Mandarin dan bahasa Indonesia memiliki kesamaan. Kesamaan terbesar keduanya adalah dari cara penekanan karakteristik benda atau hal. Selain itu, dalam pembatasan ruang lingkup hal juga memiliki kesamaan yang tampak jelas antara keduanya. Beberapa kata bantu bilangan universal dalam bahasa Indonesia dapat langsung diterjemahkan dengan kata bantu bilangan universal dalam bahasa Mandarin, akan tetapi terdapat juga beberapa yang tidak dapat tergambarkan sepenuhnya.

Tabel 1. Perbandingan kata bantu bilangan universal dalam Bahasa Indonesia - Bahasa Mandarin.

\begin{tabular}{|c|c|c|}
\hline \multicolumn{2}{|c|}{ Kata Bantu Bilangan Universal } \\
\hline \multicolumn{2}{|c|}{ Bahasa Indonesia } & $\begin{array}{c}\text { Bahasa } \\
\text { Mandarin }\end{array}$ \\
\hline \multirow{6}{*}{ Semua } & $\begin{array}{c}\text { di depan } \\
\text { semua ( }\end{array}$ & 所有 \\
\cline { 2 - 3 } & $\begin{array}{l}\text { semua (di } \\
\text { belakang) }\end{array}$ & 全部 \\
\hline
\end{tabular}

\begin{tabular}{|c|c|c|} 
Seluruh & 全部 \\
\hline Segenap & & 全部、所有 \\
\hline Segala & 全部、所有、一 \\
& 切 \\
\hline
\end{tabular}

Tabel di atas membuktikan bahwa kata bantu bilangan universal dalam kedua bahasa ini tidak dapat langsung diterjemahkan. Contohnya, terjemahan dari " - " ke dalam bahasa Indonesia "Satu", tidak ada makna lain selain "Satu", sehingga mudah diterima. Namun, dalam penerjemahan kata bantu bilangan universal tidak demikian, sebab memiliki kententuan dan karakteristik yang berbedabeda. Sebuah kata bantu bilangan universal dalam bahasa Indonesia bahkan dapat diterjemahkan dengan tiga kata bantu bilangan universal bahasa Mandarin. Karena aturan yang rumit, pelajar Indonesia sulit memahami kata bantu bilangan universal bahasa Mandarin.

4.1 Kesamaan antara kata bantu bilangan universal Bahasa Indonesia dan Bahasa Mandarin

Uraian di atas telah menjelaskan beberapa kesamaan di antara keduanya, terutama dalam penekanan terhadap benda atau hal-hal yang mengikutinya. "全部" dalam bahasa Mandarin menekankan pada kesatuan benda atau hal, "Seluruh" dan "Segenap" dalam bahasa Indonesia juga menekankan pada keseluruhan benda atau hal. Karena ruang lingkup dari "全 部" relatif luas, “全部” juga berlaku untuk hal yang dapat dikategorikan atau berjenis banyak, "Semua" dan "Segala" juga memuat ketentuan ini. Oleh karena itu, "全部" umumnya dapat 
dipertukarkan dengan empat kata bantu bilangan universal dalam bahasa Indonesia. Dengan prinsip yang sama, " 所有 " menekankan pada penggabungan dari banyaknya suatu hal, seperti kata "Semua" dalam bahasa Indonesia. Akan tetapi dalam banyak kasus, "所有" bisa juga diganti dengan kata "Segala" dan "Segenap". Terakhir, "一切" berfokus pada peringkasan dari jenis-jenis hal. Makna "Segala" dalam bahasa Indonesia adalah menekankan pada hal yang banyak jenisnya, dan keduanya memenuhi persyaratan satu sama lain. Selain itu, saat kata "Semua" muncul dalam kalimat "kala akan datang", akan bermakna sama dengan "一切". Uraian di atas membuktikan bahwa kata bantu bilangan universal dalam bahasa Indonesia dan Bahasa Mandarin memiliki arah yang sama, hanya terdapat perbedaan tipis, sehingga tak heran jika pelajar Indonesia seringkali salah dalam memahami.

4.2 Perbedaan antara kata bantu bilangan universal Bahasa Indonesia dan Bahasa Mandarin

Meskipun memiliki arah yang sama, namun tetap terdapat perbedaan di antara keduanya. "Segenap" dalam bahasa Indonesia hanya bisa diikuti dengan kata-kata yang berhubungan dengan manusia sehingga membatasi ruang lingkup kata tersebut. Namun, aturan ini tidak berlaku dalam kata bantu bilangan universal Bahasa Mandarin. Hanya saja, kata bantu bilangan universal dalam bahasa Mandarin terdapat aturan waktu. "一切 " umumnya digunakan di kalimat masa kini dan masa depan, "全部" digunakan di kalimat masa lalu, dan "所有" cenderung bebas. Tetapi tidak terdapat ketentuan tersebut dalam bahasa Indonesia, kata bantu bilangan universal manapun tidak memiliki batasan waktu.

\section{Faktor Penyebab Kesalahan}

Berdasarkan temuan penulis selama pembelajaran dan pengajaran bahasa Mandarin, faktor penyebab utama kesalahan pelajar Indonesia dalam mempelajari kata bantu bilangan universal adalah sebagai berikut.

\subsection{Transfer Negatif Bahasa Ibu}

Ketika pelajar tidak terbiasa dengan aturan bahasa tujuan, mereka hanya dapat mengandalkan penguasaan bahasa ibu. Hal ini tentunya membuat para pemula akan membuat banyak kesalahan dalam proses belajar bahasa Mandarin, terlebih lagi kata bantu bilangan universal, yang sendirinya sudah memiliki aturan yang rumit dalam bahasa ibu. Jika mengandalkan bahasa ibu untuk memahami kata bantu bilangan universal bahasa Mandarin, pasti akan muncul banyak kesalahan. Misalnya:

(1) Saya berharap semua dapat berjalan dengan lancar.

我希望一切能够顺利进行。

(2) Sebenarnya semuanya hanyalah pikiranmu saja.

其实这一切都是你想出来 的。

Contoh di atas adalah terjemahan yang benar, akan tetapi beberapa pelajar Indonesia 
menerjemahkan (1) menjadi "我希望都能顺利

", dan mengabaikan penggunaan "所有", "一切

" dan "全部" dengan menerjemahkan "semua" menjadi "都". Sebenarnya, kalimat tersebut tidak memiliki kesalahan besar, hanya saja tidak sesuai dengan masalah yang terkait, dan dengan menerjemahkan "semua" dengan "都", akan lebih memperumit pemahaman tentang kata bantu bilangan universal. Selain itu, "saya" berarti "我"; "berharap" berarti "希望"; "dapat" berarti "能"; "berjalan dengan lancar" berarti " 顺利 ". Jelas bahwa semua diterjemahkan berdasarkan kata tanpa sedikitpun mengubah urutan kata. Dalam kasus (2) juga muncul kesalahan yang sama, beberapa pelajar Indonesia akan menjawab “其实所有你的想 法而已”, “Sebenarnya” berarti “其实”; “semuanya” berarti “所有”; "hanyalah" tidak ada terjemahannya sehingga diabaikan; "pikiranmu" berarti "想法" ; "saja" berarti "而 已". Semua kesalahan ini adalah aturan tata bahasa dari bahasa ibu. Kesalahan ini disebabkan oleh pelajar yang sering menggunakan pengetahuan bahasa ibu mereka untuk memahami dan menggunakan bahasa target ketika menemui kesulitan.

5.2 Transfer Negatif Pengetahuan Bahasa Target

Dalam banyak kasus, pelajar sering mengandalkan pengetahuannya terhadap bahasa target yang masih terbatas yang kemudian digunakan secara tidak tepat sehingga menyebabkan terjadinya kesalahan. Misalnya:

（1）我们班全部都会学汉语。
（2）全部班都有一个班长。

（3）我希望一切都可以成功得毕业。

Dalam kasus (1), pemahaman pelajar tentang "会" yang belum lengkap menyebabkan terjadinya kesalahan dalam kalimat. Seharusnya adalah "我们班都在学习汉语", meskipun kalimat tersebut terlihat sedikit aneh, tetapi membuktikan bahwa di kelas lain tidak semua murid sedang belajar bahasa Mandarin, masih ada beberapa orang yang belajar bahasa lain, sedangkan " 我们班 " semuanya mempelajari bahasa yang sama. Kasus (2), seharusnya tidak menggunakan "全部" dalam kalimat tersebut, yang tepat adalah "每个班都 有一个班长", kasus ini menunjukkan bahwa penguasaan pelajar terhadap "全部" masih kurang baik, sehingga menggunakan cara menerka-nerka. Terakhir, kasus (3) “一切” tidak memiliki objek yang jelas, dan penguasaan kata "得" yang masih kurang baik.

Fenomena terlalu menggeneralisasi ini merupakan gangguan utama bagi pelajar pemula, mereka tanpa sadar menggunakan cara menduga-duga dan menggunakan apa yang baru dipelajarinya untuk digunakan pada semua situasi secara tidak tepat, sehingga menyebabkan terjadinya kesalahan.

\subsection{Lingkungan belajar}

Ketika mempelajari bahasa kedua, lingkungan belajar merupakan faktor eksternal yang juga penting. Namun, pelajar Indonesia hanya menggunakan bahasa Mandarin untuk berkomunikasi dengan guru, sebagian besar masih menggunakan bahasa ibu untuk 
berkomunikasi dengan teman sekelasnya, dan di masyarakat luar bahasa Mandarin sama sekali tidak dapat digunakan.

\section{SIMPULAN}

Penguasaan terhadap tiga kata bantu bilangan universal dalam penelitian ini, tingkat kesalahan "一切" adalah yang paling tinggi, sedangkan tingkat kesalahan "所有" paling rendah, karena ruang lingkup penggunaan "所 有" yang lebih luas, bebas, tidak terkekang oleh banyak ketentuan. Sedangkan kata bantu bilangan universal bahasa Indonesia "semua", "segala", "seluruh", dan "segenap", setiap katanya juga memiliki banyak aturan, sehingga pelajar akan menerjemahkan setiap kata tersebut, misalnya “semua" menjadi “所有”; “seluruh” menjadi “全部”; dan lain-lain. Namun faktanya, kata-kata tersebut tidak dapat dibandingkan satu persatu, karena satu kata bantu bilangan universal bahasa Indonesia bisa saja mengandung makna dari beberapa kata bantu bilangan universal bahasa Mandarin sekaligus. Oleh sebab itu, mahasiswa sering menyalahgunakan kata bantu bilangan tersebut

Berdasarkan penelitian terhadap kata bantu bilangan universal "全部", "所有" dan "一切" ini, peneliti memahami lebih dalam tentang perbedaan penggunaan kata bantu bilangan universal bahasa Mandarin dengan penggunaan kata bantu bilangan universal bahasa Indonesia. Melalui analisis yang komprehensif, ditemukan permasalahan yang dialami pelajar Indonesia ketika menggunakan kata bantu bilangan universal bahasa Mandarin "全部", "所有" dan "一切".

\section{DAFTAR RUJUKAN}

Sugiono. (2012). Metode penelitian kuantitatif, kualitatif dan R\&D. Bandung:Alfabeta.

Chen yining.(2006). Kata bantu bilangan universal dan kata bilangan berada. Xin gaokao.

Fu bo. (2000) .contoh penggunaan kosa kata yang sering digunakan pada pengajaran Bahasa mandarin. Beijing Language and Culture University.

Peng Xiaochuan, Yan Liming (2007). Arti kata dari "segala, segenap, seluruh dan semua . Pengajaran Bahasa mandarin dunia .

Wang Tingfu. (1987) penjelasan tentang kata bilangan segala. Jurnal pengajaran Zhen jiang.

Yang fan. (2013). Analisi pengajaran kata bilangan Bahasa mandarin. Normal university Henan.

Shi Yongxing.(2013) Perbandingan kata bilangan antara Bahasa Mandarin dan Vietnam. Normal University Dong bei.

Arti dari kata bantu bilangan Universal http://baike.baidu.com/view/1830968.ht $\underline{\text { m?fr=aladdin }}$ 